\title{
Editorial: Critical Zone (CZ) Export to Streams as Indicator for CZ Structure and Function
}

\author{
Julia Perdrial $^{1 *}$, Pamela L. Sullivan ${ }^{2}$, Ashlee Dere ${ }^{3}$ and Nicole West ${ }^{4}$ \\ ${ }^{1}$ Department of Geology, University of Vermont, Burlington, VT, United States, ${ }^{2}$ College of Earth, Ocean, and Atmospheric \\ Science, Oregon State University, Corvallis, OR, United States, ${ }^{3}$ Department of Geography/Geology, University of Nebraska \\ at Omaha, Omaha, NE, United States, ${ }^{4}$ Department of Earth and Atmospheric Sciences, Central Michigan University, \\ Mt. Pleasant, MI, United States
}

Keywords: critical zone, stream, system, interdisciplinary, catchment

\section{Editorial on the Research Topic}

\section{Critical Zone (CZ) Export to Streams as Indicator for CZ Structure and Function}

\section{OPEN ACCESS}

Edited and reviewed by:

Alexandra V. Turchyn

University of Cambridge,

United Kingdom

*Correspondence:

Julia Perdrial

Julia.Perdria/@uvm.edu

Specialty section This article was submitted to Biogeoscience,

a section of the journa

Frontiers in Earth Science

Received: 03 December 2019

Accepted: 04 February 2020

Published: 25 February 2020

Citation:

Perdrial J, Sullivan PL, Dere A and West N (2020) Editorial: Critical Zone

(CZ) Export to Streams as Indicator for CZ Structure and Function.

Front. Earth Sci. 8:37.

doi: 10.3389/feart.2020.00037
The critical zone (CZ) is commonly defined as the zone of life, spanning from the tops of the tree canopy down to the actively cycled ground water (Brantley et al., 2007; Chorover et al., 2007; Richter and Mobley, 2009). Considering the CZ as an open thermodynamic system, where energy and matter can exchange freely, precipitation is one of many important CZ inputs, while stream exports dissipate energy and matter (Chorover et al., 2011).

Traditionally, investigations of the Earth's surface are limited to separate parts of the CZ (e.g., the biosphere, lithosphere or hydrosphere) that are analyzed outside of their context. However, streams are integrators of the physical structure and connected nature of subsurface pore space in the CZ as well as the biogeochemical reactions that play out along the multitude of flow paths. In order to decipher such pathways and related CZ processes, we need to investigate CZ processes within the catchment context.

For example, we know that relief and soil thickness play a large role in determining hydrologic flowpaths, fluid residence time, and soil drainage class (Maher, 2011). These processes can result in changes in soil dynamics, including biogeochemistry, that cascade through the system and ultimately control stream water composition (Perdrial et al., 2015).

To probe stream water dynamics, high-frequency datasets are now increasingly generated and long-term datasets are used to identify changes in CZ processes (Crowther et al., 2016; Robinson et al., 2016; Hirmas et al., 2018). For example, many streams show long-term changes in fluxes of dissolved organic carbon (Raymond and Saiers, 2010; Perdrial et al., 2014; Zarnetske et al., 2018), weathering solutes (McIntosh et al., 2017), and nutrients (Björnerås et al., 2017; Jarvie et al., 2018), which have been related to changes in climate drivers, land use, and overall soil conditions. In particular, investigations of the relationships between solutes and their discharge regimes have shown strong potential to understand the impacts of extreme perturbations (Chorover et al., 2017; McIntosh et al., 2017) and the sensitivity of CZ processes to these changes (Abbott et al., 2018; Sullivan et al., 2018). The goal of this special topic issue is to highlight opportunities as well as limitations of streams as indicator of CZ structure and processes.

Several contributions highlight how relief, topography, and soil thickness affect CZ evolution and are reflected in stream composition. Cincotta et al. and Armfield et al. found that CZ 
composition varies drastically with landscape position in a northeastern United States forested headwater catchment, and that near stream environments disproportionally affect stream water response. Bailey et al. found that, along stream segments, the connectivity to shallow and deep upslope soils strongly impacted stream water geochemistry. Resulting elluvial soil processes were found to control stream chemistry in shallow soil environments while illuvial soil processes persisted in deep soils. Using a refined model and two contrasting forested sites, Billings et al. explored linkages between upland and depositional environments and the impact of soil organic carbon (SOC) erosion and burial on carbon budgets within watersheds on decadal to centennial time scales. They noted that the reactivity and distribution of SOC across watersheds is necessary to predict carbon storage across the landscape.

Several Critical Zone Observatory (CZO) studies reveal the importance of biotic processes and storm event magnitude in controlling elemental behavior. Olshansky et al. found that concentration-discharge patterns during snowmelt in the Jemez River Basin CZO in New Mexico indicate biologically mediated silicate weathering that propagates from the shallow $\mathrm{CZ}$ down through groundwater and strongly impacts stream water composition. A logical extension of this work is that processes impacting root/microbial respiration and biologically generated acids will alter both silicate weathering and stream water composition. Using sensor data from the Luquillo CZO in

\section{REFERENCES}

Abbott, B. W., Moatar, F., Gauthier, O., Fovet, O., Antoine, V., and Ragueneau, O. (2018). Trends and seasonality of river nutrients in agricultural catchments: 18 years of weekly citizen science in France. Sci. Total Environ. 624, 845-858. doi: 10.1016/j.scitotenv.2017.12.176

Björnerås, C., Weyhenmeyer, G. A., Evans, C. D., Gessner, M. O., Grossart, H.-P., Kangur, K., et al. (2017). Widespread increases in iron concentration in European and North American freshwaters. Glob. Biogeochem. Cycles 31, 1488-1500. doi: 10.1002/2017GB0 05749

Brantley, S. L., Goldhaber, M. B., and Ragnarsdottir, K. V. (2007). Crossing disciplines and scales to understand the critical zone. Elements 3, 307-314. doi: 10.2113/gselements.3.5.307

Chorover, J., Derry, L. A., and McDowell, W. H. (2017). Concentrationdischarge relations in the critical zone: implications for resolving critical zone structure, function, and evolution. Water Resour. Res. 53, 8654-8659. doi: 10.1002/2017WR021111

Chorover, J., Kretzschmar, R., Garcia-Pichel, F., and Sparks, D. L. (2007). Soil biogeochemical processes within the critical zone. Elements 3, 321-326. doi: 10.2113/gselements.3.5.321

Chorover, J., Troch, P., Rasmussen, C., Brooks, P. D., Pelletier, J. D., Breshears, D. D., et al. (2011). Probing how water, carbon, and energy drive landscape evolution and surface water dynamics: the Jemez River Basin - Santa Catalina Mountains Critical Zone Observatory. Vadose Zone J. 10, 884-899. doi: $10.2136 /$ vzj2010.0132

Crowther, T. W., Todd-Brown, K. E. O., Rowe, C. W., Wieder, W. R., Carey, J. C., Machmuller, M. B., et al. (2016). Quantifying global soil carbon losses in response to warming. Nature 540, 104-108. doi: 10.1038/nature 20150

Hirmas, D. R., Giménez, D., Nemes, A., Kerry, R., Brunsell, N. A., and Wilson, C. J. (2018). Climate-induced changes in continental-scale soil macroporosity
Puerto Rico, Wymore et al. found transport vs. supply limitation using concentration-discharge patterns of specific conductance and turbidity. The authors note that these relationships are especially influenced by the magnitude of events (including the category 5 Hurricane Maria) and CZ lithology.

Variations in bedrock lithology are also a theme in a cross site comparison of oxyanion dynamics at several CZOs (including Boulder Creek, Calhoun, Luquillo, and Southern Sierra). The study by Richardson et al. emphasizes the importance of deep bedrock and transport processes within the $\mathrm{CZ}$ as controls for stream water dynamics. The role of land use (agricultural and restored prairie) is investigated in the contribution by Dere et al., where solute fluxes through soils and to streams in Nebraska and Iowa are quantified. Their results indicate that changes in land use propagate to streams and drive weathering product export less than 50 years after land use change.

\section{AUTHOR CONTRIBUTIONS}

All authors listed have made a substantial, direct and intellectual contribution to the work, and approved it for publication.

\section{FUNDING}

This research was supported by the National Science Foundation, grant no. EAR-1724171.

may intensify water cycle. Nature 561, 100-103. doi: 10.1038/s41586-0180463-x

Jarvie, H. P., Edwards, F. K., Bowes, M. J., Scarlett, P., Bachiller-Jareno, N., Smith, D. R., et al. (2018). Phosphorus and nitrogen limitation and impairment of headwater streams relative to rivers in Great Britain: a national perspective on eutrophication. Sci. Total Environ. 621, 849-862. doi: 10.1016/ j.scitotenv.2017.11.128

Maher, K. (2011). The role of fluid residence time and topographic scales in determining chemical fluxes from landscapes. Earth Planet. Sci. Lett. 312, 48-58. doi: 10.1016/j.epsl.2011.09.040

McIntosh, J. C., Schaumberg, C., Perdrial, J., Harpold, A., Vázquez-Ortega, A., Rasmussen, C., et al. (2017). Geochemical evolution of the critical zone across variable time scales informs concentration-discharge relationships: Jemez River Basin Critical Zone Observatory. Water Resour. Res. 53, 4169-4196. doi: 10.1002/2016WR019712

Perdrial, J. N., McIntosh, J. C., Harpold, A., Brooks, P. D., Zapata-Rios, X., Ray, J., et al. (2014). Stream water carbon controls in seasonally snowcovered mountain catchments: impact of inter annual variability of water fluxes, catchment aspect and seasonal processes. Biogeochemistry 118, 273-290. doi: 10.1007/s10533-013-9929-y

Perdrial, J. N., Thompson, A. A., and Chorover, J. (2015). "Soil geochemistry in the critical zone: influence on atmosphere, surface- and groundwater composition," in Principles and Dynamics of the Critical Zone, eds J. R. Giardino and C. Houser (Elsevier), 173-201. doi: 10.1016/B978-0-444-63369-9. 00006-9

Raymond, P. A., and Saiers, J. E. (2010). Event controlled DOC export from forested watersheds. Biogeochemistry 100, 197-209. doi: 10.1007/s10533010-9416-7

Richter, D. d., and Mobley, M. L. (2009). Monitoring Earth's critical zone. Science 326, 1067-1068. doi: 10.1126/science.1179117

Robinson, D. A., Jones, S. B., Lebron, I., Reinsch, S., Domínguez, M. T., Smith, A. R., et al. (2016). Experimental evidence for drought induced 
alternative stable states of soil moisture. Sci. Rep. 6:20018. doi: 10.1038/srep 20018

Sullivan, P. L., Stops, M. W., Macpherson, G. L., Li, L., Hirmas, D. R., and Dodds, W. K. (2018). How landscape heterogeneity governs stream water concentration-discharge behavior in carbonate terrains (Konza Prairie, KS: USA). Chem. Geol. 527:118989. doi: 10.1016/j.chemgeo.2018. 12.002

Zarnetske, J. P., Bouda, M., Abbott, B. W., Saiers, J., and Raymond, P. A. (2018). Generality of hydrologic transport limitation of watershed organic carbon flux across ecoregions of the united states. Geophys. Res. Lett. 45, 11702-11711. doi: 10.1029/2018GL080005
Conflict of Interest: The authors declare that the research was conducted in the absence of any commercial or financial relationships that could be construed as a potential conflict of interest.

Copyright (c) 2020 Perdrial, Sullivan, Dere and West. This is an open-access article distributed under the terms of the Creative Commons Attribution License (CC BY). The use, distribution or reproduction in other forums is permitted, provided the original author(s) and the copyright owner(s) are credited and that the original publication in this journal is cited, in accordance with accepted academic practice. No use, distribution or reproduction is permitted which does not comply with these terms. 